\title{
(Un)becoming women: Indian factory women's counternarratives of gender
}

\section{Jayati Lal}

\begin{abstract}
This paper portrays the life stories of five factory workers in Delhi whose life trajectories run counter to normative femininity. As daughters and wives, they are neglected, abandoned or rejected by their families; they live alone, with their parents past the age that is their natal right, with siblings, or with families and men who are not related to them. I explore the circulation of their counternarratives and how their gender transgressions go public through ordinary forms of talk, such as gossip and rumor. I argue that their move out of the normative is not produced by, but produces, their gender politics; that their agency emerges cognitively from the telling of their stories in tandem with their interlocutors' credulity and uptake; and that the site of gender politics for working class Indian women lies in the informal subaltern publics that are formed by the circulation of their stories. Contrary to the notion of a stable unitary subject that precedes the political, these women's counternarratives demonstrate the subject-in-process as a political effect. Their alterity does not exist outside the heteronormative gender order but demarcates the boundaries of its historicity, hinting at both the internal contradictions of existing gender relations and their future possibilities.
\end{abstract}

\section{Introduction}

This paper portrays the life histories of five women factory workers in Delhi who do not follow expected gender scripts and whose life trajectories run counter to normative femininity. ${ }^{1}$ Women who experience ruptures in the expected path from their natal to conjugal families - for example, those who are spinsters, divorced, abandoned, single mothers or adulterers - live alone, with their parents past the age that is their natal right, with siblings, with husbands of their choosing, or with men who are not related to them. Their stories articulate new modes of belonging to families that are forged through alternative and fictive kinship ties and demonstrate novel forms of domesticity which reconfigure traditional patriarchal family forms. I explore the circulation of these stories in factory women's lifeworlds and the ways in which 'private' transgressions go public through ordinary forms of talk, such as gossip and rumor. Once in circulation, their stories challenge the dominant 
cultural scripts of gender, broadening the horizon of future possibilities for other women by providing new models of women's domesticity as selfsufficient breadwinners.

A key argument of this paper concerns women's political subjectivities and agency: as women embedded in conditions of acute structural vulnerability and with limited resources at their disposal, how can and do they act otherwise? I draw on the construct of 'narrative identity' to bring attention to the ways in which stories do not just describe but also shape our experiences. We live our lives as enacted scripts and gain meaning in our lives from these broader cultural narratives while, in turn, our experiences shape the meaning and contours of these stories. This recursive and hermeneutic relation between our lived experiences and the stories that articulate them, creates personal identities as 'narrative identities' (Widdershoven, 1993). My use of the term '(un)becoming women' connotes this tension between the duality of external stories, or the dominant cultural scripts according to which the five women whom I refer to in this paper are deemed improper cultural subjects on the one hand, and their lived experiences of self-transformation - of unbecoming gendered subjects - on the other hand.

Belying liberal notions of the autonomous rational subject whose resistant acts reflect her individual critical intent, these women's narratives illustrate how the subject is constituted dialogically through discourse, which s/he also constitutes. Rather than exhibiting a 'decontextualized individualism,' their gendered selves are inherently relational, 'socially situated and murkily heterogeneous' (Meyers, 2004). We will see how, despite the ways in which these narratives break with normative gender emplotments, women's revised gender identities take shape within a transformed domain of the 'familial,' through relationships with an expanded repertoire of 'kin,' and through rather than prior to their enactment in discourse. Their life choices are not the result of a piori critical gender politics but become political when they circulate through informal modes of publicity.

Reflecting on and emanating from their lived personal circumstances, subaltern women's stories circulate in publics that are formed through their shared experiences of work and participation in homosocial friendships forged in factories and their working class neighbourhoods. Their narratives articulate new forms of sociality within the domestic realm and, concomitantly, the rights and entitlements that they enjoy within it. As ideological counternarratives, their lives enlarge the social imaginary and repertoire of gender by challenging conventional plotlines and by chronicling new structures of feeling about work and family. ${ }^{2}$ Emerging from the everyday practices and tactics of working-class women's lives, they provide alternatives to and implicit critiques of the extant normative gender regime. In other words, their personal stories and narratives 'have the potential to effect change, to bring about new ways of understanding the social world and ourselves' (Jackson, 1998: 60). Thus, while narrative theory stresses the hermeneutic relationship between stories and lives, I want to suggest that the political potential of these counternarratives lies not only in 
altering the narrator's sense of self and being in the world, but also in changing the very content of the stories themselves.

These narratives are shaped by material conditions of deprivation and social dislocation. The life stories of women who do not belong to typical households exemplify the precariousness of women's traditional rights and social entitlements in the family among the impoverished and working classes. ${ }^{3}$ These are stories of women whose natal and conjugal families' have failed to fulfill their obligations to them as daughters and wives. Whether due to parental or spousal poverty and neglect, or their husband's sexual infidelities or drunkenness, they experience a breach in the patriarchal bargain that Kandiyoti has identified as characteristic of South Asia: '[familial] protection in exchange for submissiveness and propriety' (1988:283). In other words, they are denied the lifelines represented in the master narrative of a 'good woman,' but must nonetheless persist in carving out some kind of a respectable life for themselves. $^{4}$

In the absence of familial protections, women's paid employment facilitates their ability to navigate various forms of dislocation (removal, ejection, abandonment or escape) from their families. The experience of factory work subjects women workers to new regimes of governmentality and produces new modes of subjectivation to public patriarchies. But it also produces the conditions of possibility for articulating new claims for rights within the family. In some cases, factory employment provides the resources necessary to challenge the normative gender order; in others, factory work follows their gender refusals, enabling them to maintain relatively atypical independent lifestyles. In recounting their life stories, these women expressed sentiments regarding their domestic and working lives that do not easily fold into dominant gendered tropes about women's family obligations that sublimate the self in the service of family. Rather, their counternarratives of gender express different modes of selfhood and enact new forms of 'domestic citizenship' (Das and Addlakha, 2001).

In what follows I begin by briefly providing some context for this study and my focus on narratives in this paper. Next, I turn to the life stories of five women whom I refer to as 'gender outlaws,' focusing on how they arrived at their current predicaments. In the following section, I trace the politics of their gender refusals to map the architecture of factory women's political subjectivities and illustrate the conditions of possibility and sources of their agency. I argue that their move out of the normative is not produced by, but produces, their gender politics; that their agency emerges cognitively from the telling of their stories in tandem with their interlocutors' credulity and uptake; and that the site of politics for subaltern Indian women lies in the informal publics and interpretive communities that are formed by the circulation of these stories. In conclusion, I suggest that their alterity does not exist outside the heteronormative gender order but demarcates the boundaries of its historicity, hinting at both the internal contradictions of existing gender relations and their future possibilities. 


\section{The study}

These life histories were collected as part of a larger project on women workers in the garment and television industries in Delhi, for which I interviewed over 290 workers, owners and managers in twenty three firms in the industrial districts in and surrounding Delhi. The research was conducted over twenty six months of fieldwork that was undertaken over a thirteen year period (1988/89-2000/02), in conjunction with extensive workplace ethnography in the many locations of labour - from formal factories to informal workshops and domestic workplaces - where women were employed in these industries. The interviews focused on chronicling the lives of factory women workers, and included complete work-life histories and household surveys. ${ }^{5}$

Before I turn to the life stories, let me briefly explain my emphasis on orality in the analysis that follows. Since workers occupy the factory for a good part of the day, the publics that are created in factories emerge through both associational as well as discursive modalities. However, unlike their shared knowledge and experiences of the factory, the domestic experiences of factory women are disjointed by the time-space distanciation between the worlds of home and work. Knowledge about these 'private' practices circulates in a more fragmentary fashion though informal talk that occurs in workers' friendship circles and more generalized workplace sociality during unsupervised tea and lunch breaks (Figures 1-2), during slack production times, or among relatively unregulated workers on the shop-floor (Figure 3). They emerge in the public quotidian lifeworlds of the working poor as 'common knowledge' through various means: through self-disclosures; the visibility of their practices in the everyday lives of women, such as the observations of a co-worker who may also be a neighbour; and other forms of talk about them, such as gossip and rumor. The narrators and audiences of these stories form a public that is grounded in and yet which transcends associational communities that are formed at the workplace.

In examining these stories, I am especially interested in the ways in which women narrate their own and others' experiences and the range of sentiments that they express when recounting them. I want to highlight the move from the unspoken to the spoken, from the individual secret to that which is public and known, and from the invisibility of social practices that do not adhere to hegemonic norms of gender to their publicity. These are stories about practices and desires that may initially seem unfamiliar, but which also mimic and become models for others' practices and future ways of being. For the many women workers who are illiterate, who rarely if ever go out to the movies, and who do not have the time after their workdays to spend with friends or watch television, knowledge about 'other' lives comes from their co-habitation of and proximity to the social spaces of factories and their working class neighbourhoods about and in which such talk occurs. ${ }^{6}$ Once in circulation, these 


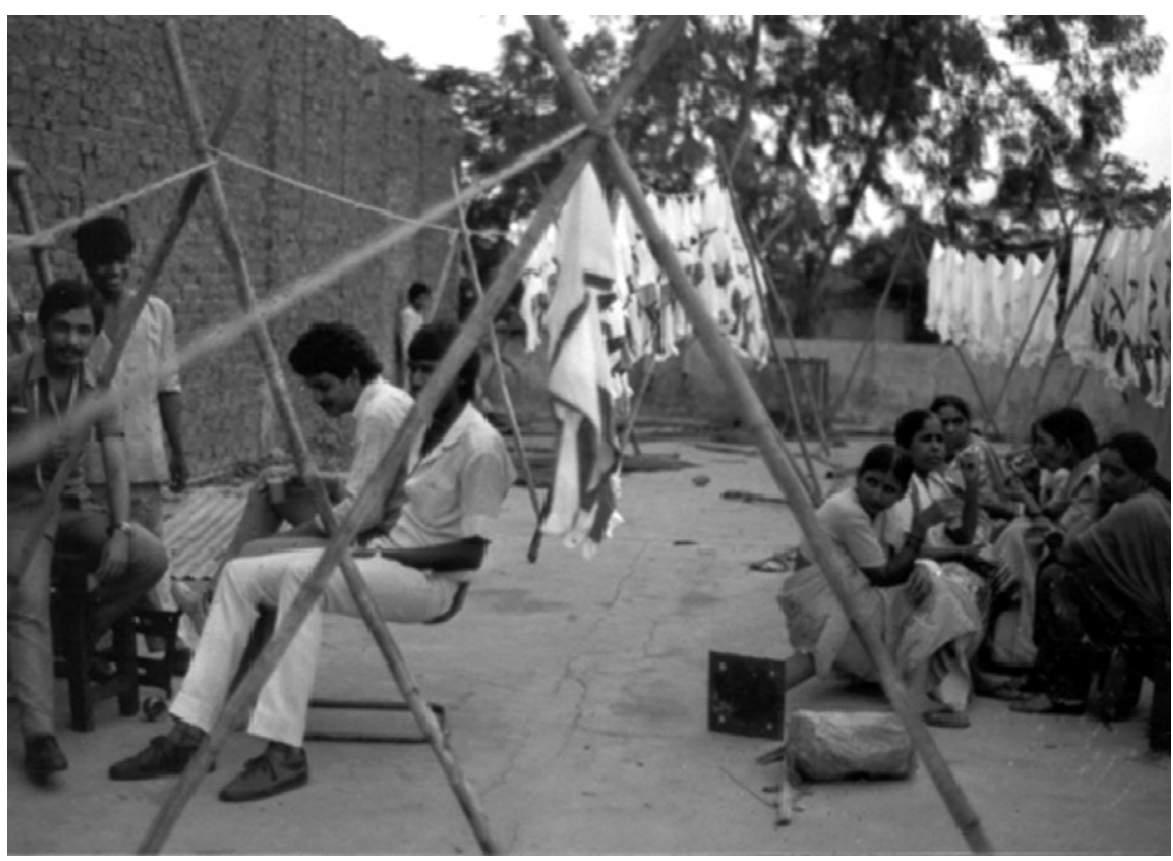

Figure 1 Garment workers enjoy conversing during a tea-break on the roof at their factory. For women workers, workplace sociality is welcome respite from the intensity of the workplace as well as their domestic routines and social isolation at home. (Photo: author, Mayapuri, Delhi, 1989)

counternarratives produce a cultural praxis of experience, becoming collective stories that stray from the doxic gender scripts which otherwise envelop the life world of women workers.

\section{Re-storying gender}

Ruth Vanita (2006) has suggested that, in the 1990s, the Indian women's movement concentrated on repairing heterosexual structures of marriage and the family through legal reforms, leading to a focus on women as victims rather than agents, and to a concern with questions of equity rather than liberation. She urges the movement to 'foreground and validate the less dominant more libratory forms' so as to foster alternative possibilities, re-imagining 'gender and sexuality to liberate humans into developing different kinds of family and living arrangements' (p. 8). ${ }^{7}$ Vanita finds examples of hope in the lives of mystics who have eschewed heterosexual structures, producing 'another kind of narrative,' one of 'opting out of the social system, followed by the formation of alternative community and friendship networks' (p. 9). As this paper will 


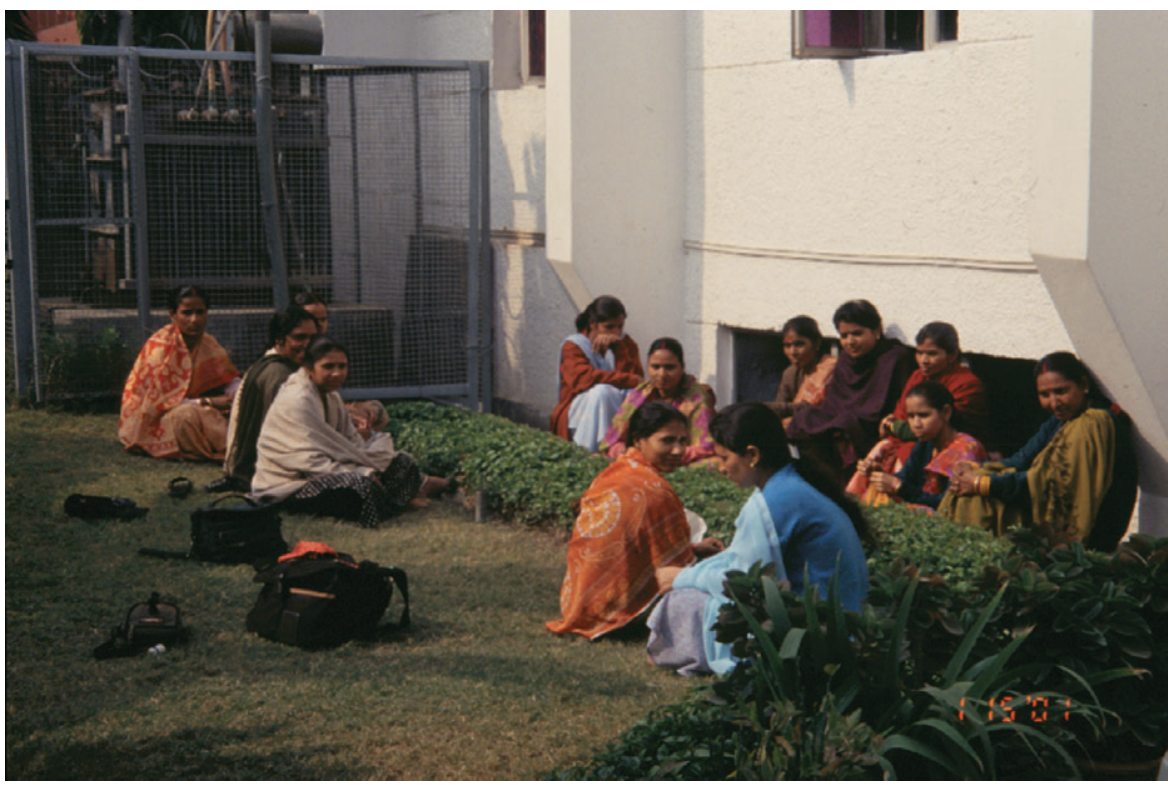

Figure 2 Garment workers during their lunch break in the factory premises. Friendship circles at work are a source of deep homosocial pleasure for women workers and one important context in which stories about coworkers circulate (Photo: author, Gurgaon, 2001)

show, we need not turn to history, fiction, or the lives of mystics to seek out such spaces of hope, for these stories emanate from and animate the lifeworlds of subaltern women.

For a variety of reasons, both circumstantial and conjunctural, these women do not transition seamlessly from being daughters and sisters to wives and mothers. Or, if they foresee doing so, they anticipate doing so with a difference. In this sense, they do not live ordinary lives, but the lives of 'gender outlaws'. I use the term 'outlaws' to signal a life that, in Carolyn Steedman's words, is lived 'outside the law' of the father $(1986: 72,80) .{ }^{8}$ The stories of women's inability and refusals to live within the constraints of gender expectations illustrate the ways in which their easy inhabitations of the normative category 'woman' have been unsettled by their classed family lives. ${ }^{9}$ These stories are suggestive of the multiple sites where practical and ideological betrayals to the bourgeois ideal of domestic femininity take place - they occur through the creation of alternative household configurations and fictive bonds of kinship, through their subjective disidentification with the hegemonic patriarchal household and its attendant femininities, and their commitment to and desire for alternative affective communities at home and at work. ${ }^{10}$

However, it is also the case that their lives are not extraordinary for the following reasons. First, their lives are conjunctural, precipitated by new 


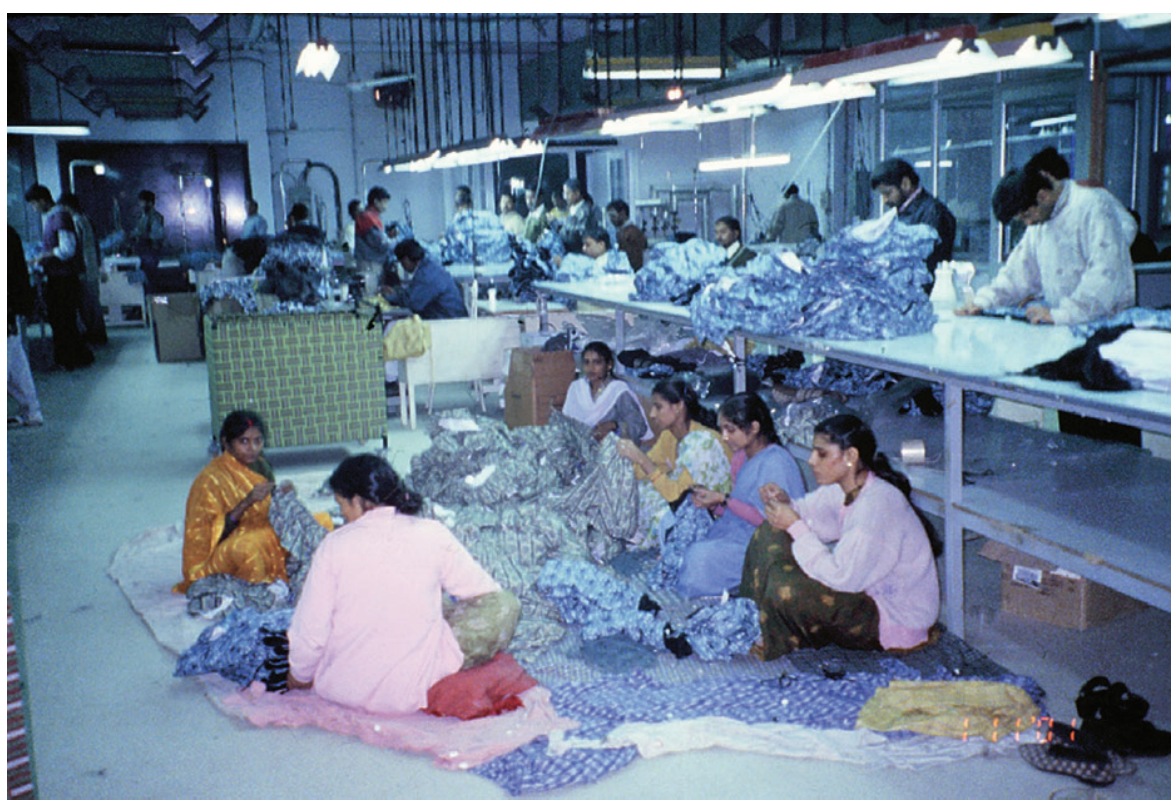

Figure 3 Women thread cutters who are casual contract laborers working on the floor in the finishing department of a garment firm. Because they are paid piece-rates, their labor is less regulated; they are thus free to talk and gossip amongst themselves as they work (Photo: author, Gurgaon, 2001)

opportunities and demands for women's factory work in the late eighties. The experience of work was becoming more commonplace as factory work became more available to and widespread among women, providing alternatives to dependency on husbands as a means of economic support. Second, these events and lives become embedded in women's quotidian worlds and everyday knowledge through mundane gossip and talk that animate workers' routines at work and in their neighbourhoods. Finally, not only do these stories have a broad reach that encompasses the multitude of factory workers, but they also reach deep into the psyches of women workers, as they generate new sentiments regarding work that culturally and emotionally normalize the role of work in working women's lives. These stories express sentiments that extend beyond shame or bitterness about the necessity to work; they include expressions of pleasure in and anticipation for work, and of work as a source for a newfound sense of worth and independence. Let me turn now to some brief vignettes drawn from their life stories.

Savitri: 'Now, I don't want to get married'11

Savitri was a thirty-three year old single migrant from Kerela who had been working as a wiregirl at Telco for eight years when I interviewed her. ${ }^{12} \mathrm{Her}$ 
narrative works against singleness as 'deficit identity' (Reynolds and Taylor, 2005 ) in the context of the dominant narrative of Indian womanhood regarding the inevitability of marriage and reproductive heterosexuality. Savitri came to the city with her brother, following in the footsteps of her twenty-eight year old sister, Sarada, who had moved to Delhi to be with her husband a year before they arrived. In contravention to customary practice, three of her four younger sisters - Sarada (28), Amily (27), and Kamini (25) - were all married before Savitri. When I asked her whether her parents had looked for a prospective husband for her, Savitri said that she didn't know why her parents married her sisters before her.

They were looking for me but they married her [Sarada] before me [...] Now, I don't want to get married [. . . ] My younger sisters have got married [but] I don't want to get married [. . . I I have grown old, so it's OK.

Although she is emphatic that she will not get married in the future, that she does not want to get married, Savitri seems to suggest that the reasons for this are because it is too late, and that it would be unseemly for the older sister to marry after the younger siblings, especially when they have children. She repeatedly ended her sentences with 'It's OK' (theek hai), echoing a resigned acceptance of her situation. Later on our conversation, when I posed the possibility that she may want to marry in the future, Savitri said, 'My sister has two children and the younger sister is pregnant and has one child, and ... the [next] youngest one is two months pregnant, and I am the eldest. So if I get married [now], it wouldn't look good'.

Savitri had been living with Sarada and her husband since she came to Delhi eight and a half years ago. They share a one bedroom flat that has a private bath, but no separate kitchen. The bedroom has been rented out, so the three adults and two children ( 3 years and 5 days old), share the main room where they sleep and cook. Despite the tight quarters that they share, as an earning member, she is welcome in her sister's home, shares the housework with her, and provides an inbuilt extended network of care for her sister's children. However, she can only live this life as long as she is employed and contributes to the joint household income. She therefore foresees the necessity of working in the future, further extending her life as a single employed woman in the city. While living with one's married sister or other siblings as a single migrant in a far away city is an established practice among women workers who expect to return home for their marriage, it is not a temporally bracketed trajectory for Savitri. Being in the unusual situation of the eldest older but (still) single sister clears the way for Savitri to work indefinitely in the future since she does not (or cannot) anticipate marriage. Moving away from her parents home, where she would always be marked as the 'too-oldto-be-married-eldest-daughter,' Savitri reworks the category 'spinster' by extending what is typically a temporary residential pattern into an indeterminate future, forging a novel household set-up in the city. Savitri's migration 
from Kerela to Delhi for work interrupts the usual route of single women from their natal to their conjugal homes, where work patterns fit into but do not in themselves define or shape this movement. Because of her living arrangement with her married sister, she is able to keep within the normative bounds of respectable femininity even as she acknowledges with resignation that it is too late for her to marry.

Although I did ask, I did not push for an answer as to why Savitri did not marry. During our interview, it was clear that she was either being deliberately evasive, or that it was too private a matter to share with a stranger who showed up at her factory and whom she brought home for a conversation one day. I did not pursue her claim that she did not want to get married. But I did get a provisional answer to the question from an unlikely source. When her co-worker Sharifa heard that I had also interviewed Savitri in her home, she offered this piece of unsolicited gossip: Savitri was not married because she could not have babies after her 'operation'! I had no reason to believe Sharifa's claims. Indeed, they did not fit with the time-line of Savitri's operation, which she said had been for her gall bladder, and which had been relatively recent, while her sister Sarada had been married for eight years. It is quite possible that Sharifa was referring to another operation that Savitri had prior to her coming to Delhi, which had rendered her sterile. However, the veracity of the gossip is less consequential to my point than its circulation and source. ${ }^{13}$ That it should come from Sarifa (whose life story I discuss next), herself a gender outlaw, should not surprise us. By repeating and using the norms of gender to discipline others, Sarifa likely hopes to model and represent herself as an obedient gendered subject. But its circulation tells us that this attempt at corralling 'mischievous' behavior, which does not conform to the normative gendered practices or desires that women subjects should possess, is what brings it into circulation and into the realm of sociality. In so doing, it expands the repertoire of possible future relationships that women have to their work and families, and hence too the future 'inventory' of gender (Connell, 1987).

Sharifa: 'My only work was to cry' ${ }^{\text {'4 }}$

Sharifa was twenty-six years old when I met her. Like Savitri, she worked as a wiregirl in Telco, and lived within walking distance from the factory in the working-class neighbourhood of Govindpuri. Married at the age of twenty to a man ten years her senior, she lived with him for a year-and-a-half in a village in Uttar Pradesh, where he worked. Her father was a government clerk in the local court in Kanpur until he died, when she was around five years old. Her widowed mother raised Sharifa and her two elder sisters. Although she did not work, because 'in UP women observe burqa,' ${ }^{15}$ she was able to support her three daughters by renting out a portion of their house and by teaching children Urdu to read the Kuran. Sharifa is literate and had graduated from high school.

Sharifa's problems started around four months after her wedding, when her husband brought another woman into their home who he claimed to have 
married prior to their marriage. She is filled with disbelief when he tells her that he has married twice. Although she is in complete shock, she recounted her response, 'I said "all right" (theek hai), and I started crying'. Sharifa's voiced acceptance of the situation soon after her learning of his first marriage speaks volumes about the cultural context within which she is embedded. While signaling her acknowledgement of his right to another wife as a Muslim, and thus the necessity that she should tolerate it, she is not happy about the fact that she is not his only wife, and especially that she did not know of this marriage prior to her wedding. Sharifa refused to name the first wife throughout the interview; she spoke of her disparagingly and only in the third person, referring to her as 'that woman' (voh aurat). In her narrative, she portrayed his first wife as a strong and willful woman who was older than her husband and therefore easily able to manipulate him. This interpretive strategy, which downplayed her husband's culpability, likely enabled her to cope with her anguish at her changed circumstances and her status as the second wife.

When I asked her why she left her husband, she replied, 'They turned me out [of the house], they used to beat me ... Both of them used to fight and he used to beat me'. He beat her a lot, she says, but not the other wife: 'She would have killed him if he would have touched her'. Although it is impossible to assess the truth of her claims, what is more relevant to our understanding of Sharifa is her self-construction of being victimized by the other woman who is seen as more powerful than both herself and her husband. After a particularly bad and public episode of physical abuse from the first wife six months after her wedding, Sharifa left her husband and went back to her mother's house. In her narrative of the end, she speaks of her burkha falling, which marks a symbolic end to her marriage and her honor, and which she no longer wears. 'Now I don't wear it. I haven't worn it for the last two years. What is its use now? It is just an added expense'.

Sharifa described her sense of desolation and depression in the months that followed; how she let herself go, and had no interest in life. Eventually she realized that she could not stay on indefinitely with her mother, who wanted her to return to her husband: 'how could I live off my mother?' Sharifa left for Ghaziabad (an industrial city on the outskirts of Delhi) to look for work, informing her mother after the fact. Initially she stayed with some old neighbours from her natal home who knew her mother. Through them she is put in touch with a young boy, Aman Singh, who was able to get her the job in Delhi at Telco. Seeking at first the shelter of people who are known to her family, Sharifa slowly makes her own way into the city, building relationships of fictive kinship that cement relationships of dependency and need. Aman Singh also finds her a place to stay in Delhi, which was close to where he lived. She is immediately able to establish a rapport with her landlord: 'From [the beginning] I call her masi [maternal aunt]. She has a lot of affection for me, [she treats me] just like her daughter'. These relationships provide her some protection as a young married Muslim woman who is alone in the city, where the only person she knows is a young boy who cannot easily be brought into the 
ambit of fictive kin. Sharifa moved four or five times in the four years that she had been in Delhi. The relationships she has with her landlords who, she says, 'treat me like family,' and whom she refers to in specific familial terms, help to build stability and security amidst the chaos and uncertainty in her life.

Sharifa invited me to her home for her interview, which was a one room flat that she shared with an older man from whom she sublet the room, and whom she referred to as 'Baba,' marking him as kin of an older generation. ${ }^{16}$ By all accounts it was an odd arrangement, and was remarkably unusual in her working class neighbourhood. She learned of the rental through her roommate's son, who worked as a helper at Telco. The flat consisted of a kitchen, bathroom, living room, and a balcony off the living room. They had separate cooking and sleeping arrangements which afforded her some privacy. Sharifa slept in the main room, while Baba either slept on the kitchen floor or on the balcony, depending on the weather.

While she did not volunteer information about her marriage to Baba until he asked about it, she had told his son about her situation when asking for assistance in finding a place to rent. It's likely that the son relayed this information to Baba, which made him agreeable to the set-up in the first place. Sharifa did not attempt to hide her status as a married woman who was separated from her husband. But, as she pointed out, she didn't often volunteer it either. When I asked her how she responded to queries regarding her marital status, she responded:

Yes, then I tell them. But that is why I don't get involved with anybody and tell them my whole life story. If you tell them obviously you go down in their esteem, so it's better that you don't meet people and don't tell them.

Although she could have concealed her background when looking for work, she chose not to. Perhaps it was as a strategy to gain sympathy instead of disapproval that prompted her disclosure, leading her to claim, later in the interview: 'I never hide it'. Notwithstanding her attempts to be aloof from those around her, Sharifa lived in a dense working class neighbourhood that abuts the industrial estate and factory where she worked. Several of her co-workers also lived in Govindpuri, and I accompanied a group of women who frequently walked home with her from the factory to their neighbourhood on several occasions. Under such circumstances, it is likely that her living arrangement was an open secret among her co-workers, her immediate circle of acquaintances and friends, and her neighbours.

Sharifa was unable to depend on her natal family because her mother was supporting her elder widowed sister who is uneducated and has a child, and who therefore has a greater entitlement to her mother's assistance since she is unable to support herself. In the absence of a brother who would provide for his mother and sisters in such cases, Sharifa's only recourse is to fend for herself. As she put it, 'I had a fight with my husband, and I don't even have a brother. We are only three sisters [. . . ] how long can I sit at home and eat'? At 
twenty six, she is young and could certainly marry again. This would give her mother peace of mind while also easing the burden of the cost of incidentals that she currently provides for Sharifa. In the interim, however, since her husband has not divorced her, she cannot remarry. ${ }^{17}$ Sharifa is caught in a double-bind: she unable to depend on her natal family for material support because her mother has a limited income and is already supporting one daughter and grandchild; yet she cannot move forward with another marriage as a way to secure her future. She must continue to work in order to maintain her independence. But there is no going back for her: 'There was no question of my going back. Even if I don't work, I have decided I will not go back over there,' she says.

Vidyalakshmi: 'Caring for my parents gives me happiness ${ }^{\text {'18 }}$

Vidya was born and grew up in Delhi, though her parents are from Tamil Nadu in South India. She began working at the age of seventeen, when her father was having a dispute in the shop where he was working, during which he was not being paid. When I met her, she was twenty four, divorced and living with her parents, and had over seven years of work experience. She worked as a wiregirl in a television company in Delhi for two years, but gave that job up when she moved to Madras to live with her husband when she was married at eighteen. Two months after they were married, her husband rekindled a premarital affair with a woman whom he had wanted to marry, but forswore in the face of parental pressure to marry Vidya instead. The situation worsened as his lover's visits to their house became regular and her husband physically abused her. With her parent's aid, Vidya returned to her natal home in Delhi, barely six months after her wedding. Upon her return, Vidya said that her neighbours and relatives used to make snide comments about her living apart from her husband. Her parents were also very upset about the whole affair, and for a while after her return, tried to persuade her to go back to her husband. Vidya was adamant about not returning to him and eventually, her husband divorced her in absentia and married the other woman. He does not send her any maintenance money, nor does she claim any financial support from him, which she would be entitled to if the divorce was legal.

Two months after her return to Delhi, Vidya went back to work. Although her life returned to the familiar pattern it had before her marriage, the pain of her failed marriage continued to haunt her. She recounted leaving a permanent job at a television factory in Mayapuri after working there for two years because, she said, 'the girls used to taunt me about my marriage'. She had not disclosed the fact of her marriage when she applied to work there but, 'later,' she tells me, 'they found out about it'. After hearing about how she had left a good job because of gossip among her co-workers about her marriage, I was surprised when Vidya told me that she had informed the company where she was currently employed (and where she had been working for eight months) about her personal history when she interviewed for the job: 'I told them all about my marriage and separation, and they sympathized with me. Because 
they know about my situation, I don't think they will dismiss me'. Since it had been about two years ago that she had reacted so dramatically to her co-workers' gossip, it's possible that by now she was less sensitive to what people say about her failed marriage. She may also be less concerned that the people at this factory know about her divorce since this job, which is in Noida, is very far from her home in Delhi's Karol Bagh. It may also have been a deliberate strategy on her part to elicit sympathy regarding her plight, in order to secure the offer of a job because she would have been considered more 'needy' during her interview. ${ }^{19}$ Whatever the reasons for her making this knowledge public, its effects are transformative: it supplements and augments components of her gender subjectivity that are defined outside the narrative of a 'failed' marriage. Pulled out of the secret into the spoken via gossip, and pushed out into the public via self disclosure, her story helps to rewrite collective understandings of the marital experiences and working lives of 'real women' whose gender scripts stray from the normative ideal.

Vidya's divorce changes the future that she had anticipated for herself as a wife and mother when she got married. She returns to live with her parents, successfully obtains work after returning to Delhi, and expects to continue to work in the future. She reworks her anticipated future as oriented to a life that is devoted to her parents, rather than a nuclear family of her own. '[M]y only mission in life is to keep my mother and father happy and comfortable; I don't want to do anything for me. Caring for my parents gives me happiness'. In emphasizing her devotion to her parents' well-being, Vidya extends the script for respectable femininity - the good and dutiful daughter - into her married life. In doing so, she is appropriating the role of a good and dutiful son, since it is sons who are responsible for looking after their aging parents in a joint virilocal Hindu family. The dedication of self to others, and the nonindividuated sense of self and selflessness it entails, are also desirable qualities in a good wife and mother. Nonetheless, Vidya does not entertain the possibility that she may get remarried in the future; instead she imagines a future dedicated to her parents. Although her post-marital living situation is odd and is remarked upon by neighbours and family members, it is not disreputable because she is under the protection of her parents. ${ }^{20}$

Leila: 'Now I'm earning and eating, and there's a certain peace in that' ${ }^{21}$

Lelia was a 35 year old semi-skilled, illiterate garment worker who was employed as a daily wage worker in a garment factory in Punjabi Bagh. Leila's natal family, consisting of her father, stepmother, and four siblings, arranged an early and hasty wedding for her: 'I was married at thirteen, and I began staying with him right away because I did not have a real mother. I had a stepmother, and she didn't want me [in the house] ... I've been looking after myself from the beginning'. When her marriage fails because her husband was a drunkard who beat her violently, her parents do not give her refuge. They repeatedly send her back to her husband, claiming that they had fulfilled their parental obligations by marrying her. They saw this [domestic abuse] but they did not 
help me. They said, 'We had to marry you. That was our job, and we've done that. Now, whatever is in your fate is your problem. You take care of it'. She has a son after a couple of years, and lives with her husband for five years. 'Then he left me, he made me get out of the house (mere ko ghar se nikāl diyā)'. He also started rumors about her relationship with their neighbour. She recounts begging with him. 'But you didn't clothe or feed me. You only beat me, so where am I going to get food to eat? Who is going give me food?' Ejected by her husband, and rejected by her natal family, her sense of abandonment is complete.

Because of her uncaring step-mother, Leila is denied the traditional entitlement of a daughter of maintenance by her natal family until puberty, and shelter when she needs refuge from her marriage. Consequently, when she is kicked out of their house by her alcoholic and abusive husband, she moves in with a man who sheltered her several times from her husband's violence. She described how he once bought medicines for her when she was unwell.

Well, when he began spending money on me, then people began to talk and to gossip. And then they started maligning me, then I thought, 'If I am disreputable in speech, then why not actually be with him in deed?' So then I started living with him, and it's been ten to fifteen years since we've been living together.

Eventually her lover got married, and proposed that they all live together. She claimed that this had happened surreptitiously, when he went out of town for a trip. 'I cried, and wanted to stop living,' she says. 'I became very sad. I realized that everybody is a traitor. Now what will I do? So I saw that I must earn my own bread in order to live my life'. Leila decides to leave Bihar because she does not believe that the three of them could live together in harmony. She leaves her son in the care of her sister, and comes to Delhi with a friend who promises to find her a job, and who offers her a place to stay until she is able to support herself. However, when her lover follows her to Delhi where she has built a new life for herself after she left him, she agrees to live with him and his legal wife, referring to him as her 'husband' in conversation. 'I took him back when he came here because after all I am a woman alone. It's very hard for women to live alone here these days. When he came, I accepted his apology, and let him in'.

Not surprisingly, Leila frames her extra-marital affair as a marriage in order to bring it into the realm of the familial, even as she struggles with her lover's marriage to another woman. She repeatedly used the term wife and husband when referring to herself and her lover. Explaining her decision to leave Bihar, she said: 'when you are living with one wife, and there is another wife, and we are all living together, then it doesn't seem right'. While she may be able to represent herself as such to those who do not know her well, and perhaps even at work, she cannot maintain the fiction of marriage in her neighbourhood and among the people who witness their living situation. Even though she does not 
use the language of love and romance, but speaks instead of trust, gratitude and companionship, the affective register and the range of sentiments that Leila expresses towards her husband-lover vary quite significantly from those of women who have had arranged marriages, and who tend to speak of their marriages mostly in terms of duty. ${ }^{22}$

Speaking of her work, Leila says 'Now I'm earning and eating, and there's a certain peace in that [. . . Whatever work I get . . . as long as I get decent pay, I can eat my roti [bread] and run my household. That's it. That's all I want in my heart'. For Leila, what matters most is the independence that has come with her employment - that she is now free from her abusive husband who did not provide for her, and that she is relatively free from her protector-lover, whom she cannot depend on because of his marriage to another woman. As a lover and not a wife, she has no rights in her relationship with him. Although he followed her to Delhi, ostensibly to be with her and because he missed her, he could also leave at any time and is under no legal obligation to support her. ${ }^{23}$ Led by the material realities of a bad marriage, domestic violence, and parental abandonment, Leila departs radically from what might be expected of her. Instead of staying with her abusive husband, she leans on the man who assists her, and eventually moves in with him. When her lover takes a wife, once again, she charts a new route to independence. Without her parents, husband or lover to rely on, she comes to Delhi with a friend to begin life as a self-supporting worker. When her lover follows her to Delhi with his wife, she cannot (or does not) refuse to live with him, but she will not give up her work or her newly found independence to do so. In changing the way in which work relates to and enables her unusual domestic life, Leila has resutured the manner in which work interpellates her as a gendered subject.

\section{Kanta: 'I did not want to get married'24}

Before I turn to a discussion of these life stories, let me provide a brief account of Kanta, who resituates the role of marriage in her life, producing a narrative of refusal instead of failure, as was the case with Sharifa, Vidya, and Leila, or its absence, as was the case with Savitri. Kanta was twenty eight years old and working as a wiregirl in a television factory in Noida when we met. She came to Delhi from a provincial town in Uttar Pradesh at the age of eighteen after a broken engagement. Her narrative evidenced a strong sense of caste identity: 'We are Baniyas,' she explains (traditionally a merchant and moneylending sub-caste), 'and in our community, they require a lot of dowry [when a girl is married]'. Although her family was comfortably off and her father earned well as a wholesale grain merchant, the dowry demands exceeded their means. Kanta broke off the engagement when the demands for her dowry continued to escalate after her engagement. She moved to Delhi, where her sister resided, and where her father had a home. After living with her sister for a while, she lived in her father's house with her younger brother who came to Delhi after her father died. For eight years, Kanta worked at home as a domestic piece worker, producing woollen clothes on a knitting machine that 
she had purchased, for sale at a local store. When the rates began to decline, she turned to factory work. Four years after coming to Delhi, Kanta adopted her sister's three year old son.

In short, Kanta moves on with her life - becoming a parent and provider instead of waiting for another chance at marriage. But when she does choose wedlock, almost ten years after her broken engagement, she enters into a 'love marriage,' she tells me, with a man whom she decides to marry. ${ }^{25}$ In her narrative, Kanta presents these events as a consequence of her decisions and reasoning rather than through the tropes of resignation, shame or obedience to parental directives: 'I cut off the engagement because I didn't want to do it. My father was trying to persuade me to marry' she said. And later in her interview she noted, 'And so, when I wanted to, then I got married'. In order for us to understand the significance of these changes in Kanta's life, it is less important that we settle on a determinate 'truth' about whether it was she or her parents who made the decision against the marriage. Both possibilities are likely given the historical period when this occurred, when dowry demands escalated in tandem with the availability of newly available consumer goods on the market and were widely reported in the press. ${ }^{26} \mathrm{I}$ want to draw attention instead to the work of self representation that she undertakes, which construct these as decisions that are a consequence of her assessment and reasoning.

This narrative work is productive of a kind of gendered agency that both enacts and reconstitutes the self (Code, 1995; Sclater, 2003). Her actions were not the result of a willful political choice. There was not a politics of being anti-dowry or of being anti-marriage that led Kanta to make the choices that she did, for Kanta was not initially disinclined to get married. And yet, knowing what her parents could afford, she may have drawn the line after more than one round of negotiations of spiraling dowry demands. In this case, the decision to counter convention, even if motivated by realism and economic constraints rather than by an abstract notion of individual or women's rights, would have enabled a crisis that led her to a politics of sorts: the willingness to live alone and stay single instead of risking a life of harassment, torture, and perhaps even murder at the hands of her husband and in-laws.

\section{The politics of 'refusals'}

Although Kanta may have been the only one who 'refused' to marry and, in so doing, resisted the cultural narrative of normative Indian femininity, it would be wrong to assume that, in contrast, Savitri, Sharifa, Vidya and Leila were 'victims' of patriarchy. I have used the term counternarratives to signal the ways in which each woman, in her own way, registers a refusal to inhabit the identities designated to her by the normative gender order. When Savitri's younger sister was married before her, she refused to play the role of the hopeful old maid, but moved to the city to work instead, and intends to stay there and work indefinitely as a single woman. When Sharifa's husband and 
first wife physically abuse her, she refuses to become the victimized second wife who then turns to alternative forms of dependency on her family, but comes to Delhi to support herself and lives on her own as a separated woman. When Vidya's husband takes up an extra-marital affair soon after her wedding, she refuses to play the dutiful though betrayed wife, and leaves him to live with her parents while working full-time to support them all as a divorcee and like a good son. When Leila's husband kicks her in her stomach, and out of their home, she refuses to play the long suffering abused wife, and takes up with her neighbour, who nurses her and with whom she lives as his lover even after he marries. Each woman transgresses the appropriate norms of female behavior that define family honor in North India which 'emphasizes modesty, obedience, self-sacrifice, and attachment to the home' (Derné, 1994: 204; see also Papanek, 1979).

I wish to make three points about the politics of such refusals and their conditions of enablement. In the first place, it is important to note that their decisions were not an outcome of their gender politics, and do not reflect an autonomous political subject that is exercising a choice that reflects this free will, but are instead overdetermined by their contradictory social locations. A consciousness of alterity does not precede these events in women's lives although it does emerge from them to inform their subsequent choices and actions. Each woman is a subject of circumstance that leads her to craft variations on everyday life routines, drawing on her available social networks and economic resources. Not unsurprisingly, these innovations are centered in the domestic realm, and have drawn most conspicuously from and reworked kinship relations.

The other resource that they all have in common is their reliance on paid work, which enables their independence. ${ }^{27}$ Nonetheless, while the conditions of possibility for women's factory work may include fungible domestic forms, this is neither the goal of working, nor the consciously chosen route to work. Savitri, Sharifa, Vidya, Leila and Kanta have all crafted the possibility for factory work as a life practice through renegotiations with and a remaking of the 'rhetorical spaces' of family and domesticity (Code, 1995). However, rather than intentionally changing their home lives to attain this goal, they have turned (or returned) to a life of work when their lives at home changed. My point is that their move into the unconventional is not a political choice that they make in order to work. Their decision to take up factory work, as in the case of Sharifa, or to return to it, as was the case with Vidya, were tactical improvisations that were not rehearsed. They were not preceded by a politics or identity 'in-waiting,' but were possible because of the existence of alternative gender scripts in their social worlds and hence too in their social imaginary. In other words, their dislocations were preceded by some knowledge of the worlds of women's work even if they themselves had not worked before. This means that they draw on other women's stories - of failed marriages, of migration to the city, and of factory work - that are already in circulation when they devise solutions to their own predicaments. 
On the other hand, and this is my second point, women's decisions to work are not absent of politics but are productive of and produced by a 'cognitive agency' that stories their lives (Code, 1995: 3). Telling one's life story and recounting events that do not conform to customary lives raises important questions regarding the reception that they engender. The question of believability does not just rest on the listener's culpability in negating or muffling the experiences of the narrated life (such as the incredulity of a listener when the story does not meet their expectations), but also on the habitations of the plots of the stories by those who live them (Code, 1995: 82). The believability of the self to others, in other words, rests also on its believability to oneself, which requires (at a minimum) the reflexive recognition of the difference of one's own life from that of others and from the master narrative.

Although their exclusions from the normative scripts are explicitly rendered in their narratives, these women are disinclined to mark off their lives as distinct from those around them. Instead of speaking of their life trajectories as having expanded the 'improvisational possibilities' (Code, 1995: 78) that are available to women, they construct them as no different than other women's decisions to change jobs in the city in order to obtain better wages, to escape poor working conditions, or to accommodate domestic responsibilities. They strive to highlight the similarities of their tactics to the repertories of other working women who, with familial consent, combine work with the expectation of a married life and motherhood. In this sense, their life narratives are 'cognitive achievements' (Bruner, 2004: 692) and not simply realist accounts of their lives. Thus Sharifa and Savitri embed their remarkable migration to the city alone - as a divorcé and a spinster - as part of the generalities of factory workers' experiences and lives, and their shared compulsion to work. For Savitri, Sharifa, Vidya, and Kanta being (un)believably good rests on remaking kinship ties and building relations of fictive or extraordinary kinship - as witnessed in Savitri's long-term residence with younger married sister; Sharifa's reference to her various landlords over the years through the register of aunts, uncles, and 'father'; Vidhya's post-marital dedication to her parents' wellbeing; and Kanta's 'adoption' of her nephew. Leila's accommodation is the most unstable - for although she tries to bring her lover into the ambit of a husband, at best this puts her in the position of being one of two wives. But their continued use of the everyday language of gender should not blind us to the shifts in the grammar of gender in their lives.

In other words, what we see in the stories of these women, are the effects of a kind of agency that is produced in their narrative (re)constructions, as they reflectively narrate the events in their lives and weave them into their sense of who they are, have become, and are becoming (Hartmann, 1991). Making themselves 'believable,' and their transformations possible, requires anchoring their unfolding stories within the extant narratives of gender, under the cover of normative femininity (Andrews, 2004: 2; Kandiyoti, 1988: 282-3). In other words, their storytelling (mis)represents their 'cognitive agency,' but it does so strategically. Yet the idea of believability which is so intrinsic to the notion of 
telling stories is essentially dialogic in nature. Such stories require an audience, since the believability of the self to others cements the revised cognitive agency on which these improvisations rest. Thus, the epistemologies of everyday life are forged in epistemic and interpretive communities, and not as individual endeavors (Code, 1995: 4). The rhetorical and normalizing power of alternative stories emerges with their historical visibility as more women make and enact these different gender scripts, building on previously circulating stories, thereby amplifying their power (Plummer, 1996: 36). But it rests as well as in their collective recasting of the meaning that these plotlines entail. It thus rests on the work of dialogic exchange through various forms of talk that put the stories into circulation.

This brings me to my third point, which is that a political outcome and precondition of women's gender refusals rests in the publics that are formed by the circulation of such stories in women's lifeworlds. In other words, they encounter the makings of alternative lifelines in 'other' women's life stories that suggest the path of their own refusals through tales that circulate in everyday forms of talk, such as gossip and rumor. ${ }^{28}$ Because gossip puts stories about women who act otherwise into public circulation, it has repercussions well beyond the lives of those to whom it refers. The work of gossip brings the extraordinary and scandalous into the realm of everyday dialog and the realm of the possible. These stories become communal, visible, and social through their enactment via speech. When women make their stories public - whether by moving from silence to speech when they recount their stories in conversations, by bringing their practical accomplishments into visibility through nonverbal means such as renting a room alone, or by gossiping about the transgressive behavior of others - they bring new and unusual stories into circulation.

Gossip and rumor are a primary register for the transmission of gender transgressions. Not unexpectedly, I heard from another coworker in the factory where Sharifa worked about Sharifa's unusual lifestyle; Sharifa herself told me the rumor that Savitri was not married because she could not have children after a surgery; Leila responds to gossip about her in the village, and decides to move in with her lover since she has already been slandered; and Vidya is so acutely aware of and sensitive to gossip about her failed marriage that she changes jobs to get away from her co-workers. Alternatively, women tell their own stories as versions of the 'truth,' and sometimes telling their stories can be instrumentally oriented. We saw this in Vidya's hope that perhaps the management in the factory where she was working would be less likely to fire her if they knew that she was divorced, and in Leila's reference to her lover as her 'husband' at work.

Gossip as a representational regime entails stories about someone who is directly or indirectly known to their audience; about someone whom workers' can readily identify with, or aspects of their lifeworld that they can easily relate to. Although it relies on some loose form of community, gossip also produces new interpretive communities and publics. Tanika Sarkar has suggested that a 'gossipable' event 'creates a shared field of discussion and thereby creates an 
interpretive community that reads the text of the event' (Sarkar, 1997: 66). Like Sarkar, I want to draw attention to the role of gossip in creating communities among factory women, drawing the contours of working class culture, and cementing a shared understanding about the boundaries of a new moral order. Women factory workers' precarious lives make them acutely aware of the likelihood that they might just as easily encounter the circumstances of the women in these stories; and this potential link with their (possible) futures imparts pedagogic value to these counternarratives, since we 'can only learn from stories if they have a direct bearing on our experiences' (Widdershoven, 1993: 9). In this sense, gossip circulates models of behavior that produce empathetic identifications with other working class lives (Code, 1995: 134). Here, 'knowing how you feel' is the basis for forging an empathetic epistemic community: a women's subaltern pubic. ${ }^{29}$ The generative capacity of such talk is to normalize such gender troubles, and to suggest the routes that are available and the capacities that are needed to counter them. In other words, stories of Other women showcase the contingencies of their alterity, producing a repertoire of gender that enables mimesis and repetition under different circumstances in the future, and not just when necessitated by conditions of extreme exigency.

\section{Outside 'women'? On the historicity of gender/s}

The ideal of the male breadwinner, and the patriarchal protections that ensue from this model of the family, have formed the bedrock of capitalist patriarchy. In India, patterns of patrilocal conjugality have further hardened the ideal of the male breadwinner, despite unfavorable socioeconomic conditions and class differences in the ability to maintain this ideal (Joshi, 2002; Neetha, 2004). When the inaccessibility of this ideal is generalized by poverty, or internalized as an individual failure by men, the consequences for women are domestic violence, spousal abandonment, and various forms of natal disregard. Under such conditions, and notwithstanding decades of laws on the protection of women against domestic violence, there are, as Flavia Agnes has noted, 'no viable alternatives for women to opt out of marriage in terms of jobs and housing' (1992: 565). Faced with ruptures in the patriarchal bargain, and in the absence of state protections, Sarojini, Sharifa, Kanta, Leila and Vidya have had to create alternatives for themselves. In each case, it is the lack of familial support in conjunction with limited resources that sets in motion their quest for alternative means of livelihood, leading them to become factory workers.

Producing new possibilities and foreclosing old ones through their everyday practices, these women's narratives reveal the 'historicity' of gender relations (Connell, 1987: 143). Although they forge life stories that go against the dominant storyline of dependent domestic femininity, these are reluctant rather than purposive dis/locations, and uncomfortable inhabitations of the congealed categories of so-called otherness. They do not seek to distinguish 
themselves as rebels or to script their stories in the language of resistance. It might be helpful here to think of these narratives in terms of what Teresa de Lauretis refers to as the 'space off' of femininity - categories that exceed representation, yet which render those that are within discourse legible. She suggests that lesbians, feminists, and women of color 'reject or exceed the categories of a patriarchal gender system' (1987: 86) and thus occupy the space-off as 'not-women'. The idea of the space-off as the constitutive outside of the categories that make up our world productively draws attention to the ways in which these categories are a result of the operations of power. But it does not mark autonomously sought dislocations or escapes from the center so much as locations that are overdetermined by social arrangements which are 'the textual mark of social contradiction' (Hennessy, 1993: 86-7). This reading of alterity, which does not see narrative spaces-off as either outside the texts of hegemonic culture or as merely cultural, produces an understanding of how 'its materiality and the critical standpoint it enables can be tied to broad-ranging social arrangements' (Hennessy, 1993: 87).

My use of the term 'outlaw' women seeks to draw attention to sites of alterity that are not outside women but rather, as Hennessy (1993) suggests, are 'integral to the historicity of the limits of acceptability in culture'. Such women come to inhabit their otherness through dominant discourses and prevailing epistemologies and because of the limits of existing social relations. They do not seek to step outside the law, but neither do they hesitate to do so when they are excluded from the protections of domestic patriarchy. Inhabiting a key site of social contradiction in contemporary Indian society in the patriarchal family engenders their critical standpoints. Charting alternative emplotments for their lives that stray from the normative woman's biography produces an awareness of their alterity and shapes their revised gender identities, manifested in their sense of themselves as permanent breadwinners rather than contingent workers and supplemental earners.

In my reading of these narratives, I have moved away from the notion of intentionality that underlies the idea of the narrated self which can be 'tacitly valorized as an authentic expression of experience and as a manifestation of reflexive agency' in feminist accounts (McNay, 2003: 7). In showing how women downplay their transgressions through linguistic appropriations such as Leila's reference of herself as a 'wife,' or Kanta's emphasis on her (son-like) devotion to supporting her parents, I have aimed to highlight women's ambivalences regarding, rather than valorization of, their non-normative experiences. I refer to these moments as 'misrecognition' to draw attention to the ways that their narratives do not transparently mirror their authentic experiences, but are layered with psychic investments in the normative (meta) narrative that has eluded them. Moreover, I have juxtaposed their stories with others' accounts, such as gossip, and with their own actions which do not necessarily accord with their narratives. I have also steered clear of performative accounts of agency, demonstrating the constrained and often nonvoluntary nature of women's life choices. Nonetheless, I have suggested that 
their lived lives have performative effects, serving as object lessons for other women who may be similarly constrained; or in other words, that their narratives are nothing short of 'world making' (Bruner, 2004). ${ }^{30}$

The reflexive agency of this socially situated 'radical' subject is produced relationally - through interactions and in dialogue with others, in the ambit of social relationships, and embedded in institutional practices of the family and at work (Meyers, 2004; Reynolds, 2010: 36). Contrary to the notion of a stable unitary subject that precedes the political, these women's narratives demonstrate how the 'subject-in-process' is a 'political effect' (Lloyd, 2005: 6). The social text of women's lives reveal the manner in which their narrative identities emerge dialogically as they tell their stories to (and as they are told by) others, interpreting their life experiences in light of cultural narratives that have eluded them. In the lives of subaltern women, it is through the register of everyday talk, such as gossip and rumor, that publics are formed and where the political emerges. Furthermore, although these stories are about their exclusion and escape from the family, they do not abandon familial social circuits. Instead, they interrupt the doxa of gender and improvise domestic alternatives that can accommodate their difference. 'Inhabiting the gaps in the coherence of the social imaginary, these critical positions disclose the arbitrariness and historicity of its boundaries' (Hennessy, 1993: 87). Rather than inhabiting a space outside the category 'women,' they enable different scripts within the discursive limits of the social and insert them into the political horizons of the future.

University of Michigan

\section{Notes}

1 I am grateful for grants from the American Institute for Indian Studies and the Institute for Research on Women and Gender at the University of Michigan, Ann Arbor that supported this research. I would also like to thank Heidi Gottfried, Joanna Latimer, Beverley Skeggs and two anonymous reviewers for their comments on earlier drafts of this paper.

2 Counternarratives are 'the stories which people tell and live which offer resistance, either implicitly or explicitly, to dominant cultural narratives' (Andrews, 2004: 1), whose strength comes from their being 'shared stories' (Callero, 2003: 124). Counternarratives are inherently relational and positional vis-à-vis master-narratives which 'offer people a way of identifying what is assumed to be a normative experience'. I prefer this term to 'oppositional' narratives, which suggests a more conscious, pre-meditated resistance to the norm.

3 While the forms of family vary, the dominant mode would be the Hindu joint family which consists of 'a group of adult male coparceners [joint heirs] and their dependents ... wives and children' (Chawla, 2007: 8).

4 The ideal woman is embodied in the term pativrata from ancient scriptures (literally, 'husbandvow'). It refers to an ideology into which women are socialized from childhood, producing feminine subjectivity 'defined as service to the (extended) family' articulating the idea of eternal fidelity to one's husband and his family (Gabriel, 2010:125). Tanika Sarkar captures the significance of marriage in a woman's life cycle succinctly when she says, 'The good woman ... would primarily be the good wife' (1997: 85). Her observations about nineteenth century Bengal would also hold true for North India in the contemporary period. 
5 The workers' interviews were often conducted in one sitting and ranged from two to three hours, and were done in two stints: in 1988/89 with re-visits to four firms in 2000/01. Although most interviews were conducted at the worksite, some (including two of the interviews I draw on in this paper) were done at workers' homes after the workday or on the weekend. This research is the basis of a forthcoming book manuscript, Making 'Factory Women:' The Labor of Gender in Late Twentieth Century Indian Capitalism.

6 Although many workers owned small black and white televisions, during the period that I conducted these interviews, there were few programs to watch on the single government channel monopoly. Following liberalization in 1992, satellite television with multi-channel availability at reasonable rates led to a mushrooming of broadcasting choices and a democratization of viewership, including among the poor and working classes (Butcher, 1999; McMillin, 2003: 168).

7 Even in fiction by Indian women writers where one might hope to find such alternatives sketched out, the texts often end when women leave bad marriages 'because logically there is nowhere for her to go except another marriage, suicide or lonely depression' (Vanita, 2006: 9).

8 Reinterpreting her childhood experiences of growing up poor and working class in Britain during the 1950s, Steedman (1986) challenges the 'official myths' of patriarchal law and the Oedipal drama. Far from being the powerful figure depicted in these myths, she recalls her father's relative powerlessness within the family, in the eyes of the state, and when faced with minor officials. It was a similar 'failure' in the patriarchal model of the male breadwinner which impelled women to work in factories, or as industrial home-workers. Although the term gender outlaw has a distinctly queer genealogy (especially with reference to transgenders), I find it productive for the work that it does in deconstructing 'heterosexuality' as a regulatory fiction.

9 While recognizing the existence of multiple patriarchies in India (Sangari, 1995), in referring to the biography of the normative woman as inscribed in domestic femininity, I am condensing the received understanding that although the necessity of marriage and motherhood distinguish the codes of conduct of upper caste woman in 'Brahmanical patriarchy' (Chakravarti, 2009), it has also been the dominant code across castes and religions because of its hegemonic influence on lower castes, who have emulated such practices in seeking upward mobility, and because of continued customary cultural practices among groups who have converted to other religions (Gabriel, 2010: 118).

10 'Disidentification' refers to a mode of subject formation that is not compliant, desirous or identified with hegemonic norms on the one hand, nor does it oppose or reject the normative via counter-identification. Instead, it signals the recognition of its difference and maintains a critical distance from the normative subject (Alarcón, 1997; Hennessy, 1993).

11 Savitri P., August 2, 1989, Tughlakabad, Delhi.

12 All workers' names are pseudonyms, assigned to match their real names which indicate their religion (Hindu, Muslim, or Christian). Telco is a pseudonym for a television firm in Okhla industrial Estate (Phase II), where Sarojini and Sharifa, worked. The factory is close to the working class neighbourhood of Govindpuri, where many workers from Telco lived.

13 As Bruner (2004: 694) rightly reminds us, there are no criteria for 'rightness' in a person's account of their lives. Narrative adequacy does not come from veracity; rather the point of interest is 'what purpose this served for the storyteller' (Atkinson, 2002: 126). In other words, coherence and honesty are neither necessary nor achievable, since 'the point of a life story interview is to give the person interviewed the opportunity to tell his or her story in the way that person chooses to tell it' (p. 126).

14 Sarifa Parveen, July 27, 1989, Govindpuri, Delhi.

15 Burqa refers to the full body covering and veil that Muslim women wear. It is also used colloquially to refer to women's spatial restrictions and containment.

$16 \mathrm{Baba}$ is a colloquial term for an older man. It could translate either as grandfather, or as father. It is also a term of address and respect that is used to refer to older men. Given that he was a co-worker's father, I read her use of it as a fictive term for 'father'. 
17 Sharifa indicated that her husband had not divorced her. Maintenance upon divorce and spousal abandonment may be claimed under various personal laws and certain provisions of the criminal codes, but are very difficult to obtain in practice. Legal settlements have frequently been linked to women's sexual morality (Agnes, 2009). In this instance, the fact that she was living with an unrelated male, regardless of his age, would have made her claim suspect.

18 T.S. Vidyalakshmi, August 22, 1989, Noida, Ghaziabad, Uttar Pradesh.

19 Managers frequently told me that they took women's family backgrounds into account when hiring, and that they considered divorced, widowed, abandoned women and single mothers to be more reliable workers. Because of their greater need and the significance of their income to their households, such women, they reasoned, would be less likely to leave their jobs after they had been trained on the job. They were likewise biased against hiring married women for the obverse reasons.

20 Speaking of marriages among residents in a poor neighbourhood in Delhi, Shalini Grover notes that 'It is not considered unusual or unconventional for women to seek refuge [with their natal families], for in situations of marital breakdown they are not expected to live alone, as this has connotations of immorality' (2009: 12-13).

21 Leila Devi, June 13, 1989, Panjabi Bagh, Delhi.

22 'Hindu marriages have almost negligible associations with romantic emotions.... closely aligned with historical understandings of Hindu marriage, middle-class India defines love as commitment and devotion to family' (Chawla, 2007: 11).

23 It is only very recently that the 'Protection of Women from Domestic Violence Act' (2005) grants rights of maintenance and residence to cohabitees (Agnes, 2009: 62-3).

24 Kanta Gupta, August 22 and 23, 1989, Noida, Ghaziabad, Uttar Pradesh.

25 Patricia Uberoi has suggested that class and caste isogamous self-arranged ('love') marriages are increasingly tolerated because they bypass the necessity of dowry (2006: 135-6). The English term 'love-marriage' is commonly employed in India, even among the poor and in rural areas (Grover, 2009; Mody, 2002). There is a consensus among researchers that most marriages in India continue to be parentally arranged, and that they are the norm across religious groups (Chakravarti, 2009; Chawla, 2007; Mullati, 1995; Uberoi, 2006).

26 During the eighties, incidents of 'dowry-deaths' due to unmet dowry demands (especially notable in North India and in Delhi) were also covered in the press, as were Indian feminists' public protests, awareness campaigns and legal activism against dowry (Kumar, 1993; Sharma, 1993).

27 I do not mean to suggest that paid work liberates women from domesticity, or that capitalism frees them from patriarchy. A large literature that addressed this question in the 1980s problematically formulated capitalism and patriarchy in dualistic terms, and as if they coincided with the public/private divide, rather than as deeply imbricated. A more productive starting premise is the acknowledgement of both private and public patriarchies (Brown, 1981; Walby, 1990) and the recognition that women enter into 'patriarchal bargains' in capitalism which enable them to 'strategize within a set of concrete constraints' (Kandiyoti, 1988: 274).

28 Because they lie outside the purview of rational male discourse, gossip and rumor tend to be seen as primarily female and subaltern modalities of speech, and have been undervalued as a source for analytic insights (Code, 1995; Adkins, 2002). Feminist scholars have looked to gossip and rumor as counter-discourses and objects of feminist epistemology (Adkins, 2002; Leach, 2000; White, 2000).

29 I do not refer to these as subaltern 'counterpublic' spheres, which assumes both the development of an 'oppositional' political subjectivity and its public expression through 'agitational activities' (Fraser, 1992: 123-26), since I am arguing against these presumptions of what constitutes the political subject (Lloyd, 2005).

30 In other words, I have relied on both performative and narrative accounts of agency, usually thought to be in tension with each other (McNay, 2003). 


\section{References}

Adkins, K.C., (2002), 'The Real Dirt: Gossip and Feminist Epistemology', Social Epistemology, 16 (3): 215-232.

Agnes, F., (1992), 'Protecting Women against Violence?: Review of a Decade of Legislation, 1980-89', Economic and Political Weekly, 27 (17): WS 19-33.

Agnes, F., (2009), 'Conjugality, Property, Morality and Maintenance', Economic and Political Weekly, 44 (44): 58-64.

Alarcón, N., (1997), 'The Theoretical Subject(s) of This Bridge Called My Back and AngloAmerican Feminism', in Nicholson, L. (ed.), The Second Wave: A Reader in Feminist Theory, London and New York: Routledge: 288-300.

Andrews, M., (2004), 'Counternarratives and the Power to Oppose', in Bamberg, M. and Andrews, M. (eds), Considering Counternarratives: Narrating, Resisting, Making Sense, Amsterdam; Philadelphia: John Benjamins Publishing Co: 1-6.

Atkinson, R.,(2002), 'The Life Story Interview',in Gubrium, J.F. and Holstein, J.A. (eds), Handbook of Interview Research: Context and Method, Thousand Oaks, CA: Sage Publications: 121-140.

Brown, C., (1981), 'Mothers, Fathers, and Children: From Private to Public Patriarchy', in Sargent, L. (ed.), Women and Revolution, Boston: South End Press: 239-267.

Bruner, J., (2004), 'Life as Narrative', Social Research, 71 (3): 691-710.

Butcher, M., (1999), 'Parallel Texts: The Body and Television in India', in Brosius, C. and Butcher, M. (eds), Image Journeys: Audio-Visual Media and Cultural Change in India, New Delhi; Thousand Oaks, California: Sage Publications: 163-196.

Callero, P.L., (2003), 'The Sociology of the Self', Annual Review of Sociology, 29: 115-133.

Chakravarti, U., (2009) [2006], Gendering Caste through a Feminist Lens, Kolkata: Stree.

Chawla, D., (2007), 'I Will Speak Out: Narratives of Resistance in Contemporary Indian Women's Discourses in Hindu Arranged Marriages', Women and Language, 30 (1): 5-19.

Code, L., (1995), Rhetorical Spaces: Essays on Gendered Locations, New York and London: Routledge.

Connell, R.W., (1987), Gender and Power: Society, the Person and Sexual Politics, Stanford, Calififornia: Stanford University Press.

Das, V. and Addlakha, R., (2001), 'Disability and Domestic Citizenship: Voice, Gender, and the Making of the Subject', Public Culture, 13 (3): 511-531.

De Lauretis, T., (ed.) (1987), Technologies of Gender: Essays on Theory, Film, and Fiction, Bloomington and Indianapolis: University of Indiana Press.

Derné, S., (1994), 'Hindu Men Talk About Controlling Women: Cultural Ideas as a Tool of the Powerful', Sociological Perspectives, 37 (2): 203-227.

Fraser, N., (1992), 'Rethinking the Public Sphere: A Contribution to the Critique of Actually Existing Democracy', in Calhoun, C. (ed.), Habermas and the Public Sphere, Boston, MA: MIT Press: 109-142.

Gabriel, K., (2010), Melodrama the Nation: Sexual Economies in Contemporary Bombay Cinema, New Delhi: Women Unlimited.

Grover, S., (2009), 'Lived Experiences: Marriage, Notions of Love, and Kinship Support Amongst Poor Women in Delhi', Contributions to Indian Sociology, 43 (1): 1-33.

Hartmann, J.E., (1991), 'Telling Stories: The Construction of Women's Agency', in Hartmann, J. and Ellen, M.-D. (ed.), (En)Gendering Knowledge: Feminists in Academe, Knoxville, TN: The University of Tennessee Press: 100-120.

Hennessy, R., (1993), Materialist Feminism and the Politics of Discourse, New York and London: Routledge.

Jackson, S., (1998), 'Telling Stories: Memory, Narrative and Experience in Feminist Research and Theory', in Henwood, K., Griffin, C. and Phoenix, A. (eds), Standpoints and Differences: Essays in the Practice of Feminist Psychology, London, Thousand Oaks, and New Delhi: Sage Publications: 45-64. 
Joshi, C., (2002), 'Notes on the Breadwinner Debate: Gender and Household Strategies in Working-Class Families', Studies in History, 28 (n. s.) (2, July-December): 297-323.

Kandiyoti, D., (1988), 'Bargaining with Patriarchy', Gender and Society, 2 (3): 274-290.

Kumar, R., (1993), The History of Doing: An Illustrated Account of Movements for Women's Rights and Feminism in India 1800-1990, New Delhi: Kali for Women.

Leach, M., (2000), 'Feminist Figurations: Gossip as a Counterdiscourse', in Pierre, E.A.S. and Pillow, W.S. (eds), Working the Ruins: Feminist Poststructural Theory and Methods in Education, New York: Routledge: 223-236.

Lloyd, M., (2005), Beyond Identity Politics: Feminism, Power and Politics, London, Thousand Oaks, New Delhi: Sage Publications.

McMillin, D., (2003), 'Television, Gender, and Labor in the Global City', Journal of Communication, 53 (3): 496-511.

McNay, L., (2003), 'Agency, Anticipation and Indeterminacy in Feminist Theory', Feminist Theory, 4 (2): 139-148.

Meyers, D., (2004), 'Feminist Perspectives on the Self', in Zalta, E.N. (ed.), The Stanford Encyclopedia of Philosophy, Palo Alto: Stanford University Press, http://plato.stanford.edu/archives/ spr2004/entries/feminism-self/, accessed 02/03/2005.

Mody, P., (2002), 'Love and the Law: Love-Marriage in Delhi', Modern Asian Studies, 36 (1): 223-256.

Mullati, L., (1995), 'Families in India: Beliefs and Realities', Journal of Comparative Family Studies, 26 (1): 11-25.

Neetha, N., (2004), 'Making of Female Breadwinners', Economic and Political Weekly, 39 (17): 1681-1688.

Papanek, H., (1979), 'Family Status Production Work: The "Work" and "Non-Work" of Women', Signs, 4 (4): 775-81.

Plummer, K., (1996), 'Intimate Citizenship and the Culture of Sexual Story-Telling', in Weeks, J. and Holland, J. (eds), Sexual Cultures: Communities, Values and Intimacy, Houndmills, Basingstoke, Hampshire: Macmillan: 33-41.

Reynolds, J. and Taylor, S., (2005), 'Narrating Singleness: Life Stories and Deficit Identities', Narrative Inquiry, 15 (2): 197-215.

Reynolds, P., (2010), 'Disentangling Privacy and Intimacy: Intimate Citizenship, Private Boundaries and Public Transgressions', Human Affairs, 20 (1 / March): 33-42.

Sangari, K., (1995), 'Politics of Diversity: Religious Communities and Multiple Patriarchies (Part 1)', Economic and Political Weekly, 23 December: 3287-3310; and (Part 2)', Economic and Political Weekly, 30 December: 3381-3389.

Sarkar, T., (1997), 'Talking About Scandals: Religion, Law and Love in Late Twentieth Century Bengal', Studies in History (n.s.), 13 (1): 63-95.

Sclater, S.D., (2003), 'What Is the Subject?', Narrative Inquiry, 13 (2): 317-330.

Sharma, U., (1993), 'Dowry in North India: Its Consequences for Women', in Uberoi, P. (ed.), Family, Kinship and Marriage in India, New Delhi: Oxford University Press: 341-357.

Steedman, C.K., (1986), Landscape for a Good Woman: A Story of Two Lives, New Brunswick: Rutgers University Press.

Uberoi, P., (2006), Freedom and Destiny Gender, Family, and Popular Culture in India, New York and New Delhi: Oxford University Press.

Vanita, R., (2006), 'Thinking Beyond Gender in India', Gandhi's Tiger and Sita's Smile: Essays on Gender, Sexuality and Culture, New Delhi: Yoda Press: 3-13.

Walby, S., (1990), Theorizing Patriarchy, Oxford, UK and Malden, MA: Wiley-Blackwell.

White, L., (2000), 'Historicizing Rumor and Gossip', Speaking with Vampires: Rumor and History in Colonial Africa, Berkeley: University of California Press: 56-88.

Widdershoven, G.A.M., (1993), 'The Story of Life: Hermeneutic Perspectives on the Relationship between Narrative and Life History', in Josselson, R. and Lieblich, A. (eds), The Narrative Study of Lives, Newbury Park, London and New Delhi: Sage Publications: 1-20. 